\title{
Learning Environment by the Future Society: Development of School Grounds in Lithuania
}

\author{
Liutauras Nekrošius, Indrè Ruseckaite, Edita Riaubienė, \\ Vilnius Gediminas Technical University, Lithuania
}

\begin{abstract}
This paper presents particular aspects of educational function of the schoolyard, and argues that such a space could be used for educating the young generation, collaboration and interaction in creating the living environment.

Research of Lithuanian schools' architecture during the last few decades has indicated the practice of using the school courtyard that could be described as "Forgotten Space". Education scholars pay exclusive attention to the interaction between learning and playing. Urban gardening, environmental monitoring, design-build studios become integral parts of secondary or even primary education. These activities need proper environment.

The majority of Lithuanian youth attends schools built in the interwar and soviet periods that rarely fit the up-todate paradigm of education and spatial needs. This makes the school environment problematic but, at the same time, perfect as a transformation laboratory for communities as the non-generic "commissioners", potential driving force of such actions. Architects, landscape architects, urban designers and planners occasionally look at the cooperation with communities as an obstacle or formal "must". Since 2014, the Faculty of Architecture, VGTU, started to act as a catalyst activating discussions and alternative visions for changes of school spaces, mostly anticipating that the youth (students and school-children) involved would accustom themselves to active and constant co-creation and maintenance of their environment.

The overview of the school grounds development in Lithuania during the last century was performed by consistent analysis of different functions. The study of each possible function of school outdoor area was done by applying the three-aspect correlation method: the education theory, legal building regulations and school environment practice. The study of school ground as the contemporary collectively developed playscape presented the results of experimental practices on participatory design and community engagement.

Keywords: school grounds, landscape architecture of schools, educational environment, outdoor learning, participatory design, community engagement
\end{abstract}

\section{Introduction}

Contemporary urban development is increasingly based on inhabitants' participation $[1,9,12]$, but the communities desperately need encouragement, support and know-how manuals from experts, including architects and landscape architects. Nowadays, the majority of young people in Lithuania attend schools that were built during the interwar and soviet periods. It is understandable, but still disappointing, because this environment can hardly fit the up-to-date educational paradigm and meet contemporary spatial needs. Although it is emerging as a major problem, but at the same time provides for the opportunities to use the school environment as perfect transformation laboratory. It is anticipated that the youth (students and schoolchildren) involved would accustom themselves to active and constant cocreation and maintenance of their environment.

The objective of the research is to discover the particular aspects of educational function in the school grounds and to highlight the actual methods how to achieve the up-to-date learning environment by involving students and schools' communities (teachers, pupils, parents) into the environment developing process. Participatory design mode of operation has an ambitious goal - to educate the young generation to become the co-creators of their living environment.

The assignments of the paper are to make the review of the centenary development of the school grounds in Lithuania (1918-2018) observing the theoretical views, legal instructions and architectural practices; to analyse the results of experimental research and participatory practices oriented towards the modernisation of outside learning spaces; to highlight the proven methods and tools for creating or converting up-to-date educational landscape.

This paper is a part of the larger research on the educational architecture. In it, we focus on one aspect schools' landscape, which becomes more and more important in the realm of contemporary educational theory. The study contributes to further understanding of Lithuania's educational environment development from the restoration of the statehood 100 years ago, through the soviet occupation period and up to these days.

The study provides useful insights on the methods and tools that can be used in various contexts for community engagement in the development of the built environment. 


\section{Materials and Methods}

The object of the research is the school's outdoor space, which is understood as the landscape architectural and educational object. Mainly it can be named as a school plot, area, yard, playground or ground. The most comprehensive and appropriate for this research concept is that of the school ground. It can be defined as an area used for school functions (physical and mental education, recreation, representation, service). The structure of the object is dualistic, links the matter and thought, form and content, which directly refers to the landscape architecture and education. The object varies depending on the historical and cultural conditions.

The evolutionary overview of school grounds in Lithuania during the last century has been performed by consistent analysis of different functions of school grounds: sports fields, educational-experimental zones, recreation areas, service zones and representation spaces. The study of each function of school outdoor area has been performed by applying the three-aspect correlation method starting with the education theory background, then linking it with the legal regulations and correlating with the school environment practice (design projects and/or realised schools). The data for this analysis includes bibliography, iconography, drawings, archive documents. The second part of the study deals with the results of experimental practices on participatory design and community engagement.

\section{The Centenary Development of School Grounds in Lithuania}

Interview of pupils, students, teachers and empirical studies carried out during the project have shown that school outdoor spaces do not bring any memories or associations with the daily life of the school. However, a few cases in the country have shown that school communities have been actively fighting for the reduction of school grounds and their adaptation to other, non-educational needs. Therefore, it can be argued these spaces are important for school communities, but for different reasons they are "forgotten". This has been confirmed by other scholars' research as well [5]. In order to grasp the trends and opportunities in the development of school areas, it is worth looking at the historical origins of different activities in the schoolyard. In general, the following areas can be distinguished in the territory of the school: sports, recreation, educationalexperimental, service and representational.

Plot. At the beginning of the $20 \mathrm{c}$, , the Historic Revival style dominated the schools' architecture [19], therefore it was customary to build urban school buildings on the red line of the street, thus forming the perimeter line of the block (Fig. 1). Early century's school parcels were relatively small.
Therefore, their usage was very intense and variety of activities limited. In the architecture of the 1930's, there was a tendency to slightly distract the school building from the street and to install the green zone in-between. School areas were planned much bigger; it began to be enclosed with fences. Buildings still often formed the crossroad's space, but stood freely in space and did not form the perimeter of the block anymore (Fig. 2). Such design approach prevailed until the 1960s. Rural schools were built mostly in accordance with the homestead tradition. The environment of the manor schools, schools located in former manor houses, other schools located in former manor garden areas varied considerably in comparison to others. Similar to the practice of the neighbouring countries [10], schools were integrated into the manors' landscapes, adapted parts of existing welfare, but also some changes were introduced.

Construction and design normative documents (SNiP) of the 60's [27] and 70's [28] started strictly regulate the composition of outdoor spaces, sizes of different functional areas, their location and relation to the building. To understand these changing requirements, we have compared the regulations of different periods of Kaunas' high school "Saulè", built at different stages in 1914, 1925 and 1974, and used for educational needs up to these days. In 1925 the school used $7.900 \mathrm{~m}^{2}$ area [14]. According to the regulations of the 60 's, the area in size of $14.700 \mathrm{~m}^{2}$ had to be given to the school. The Contemporary Hygiene Norm [17] states just approximate quantity of the greenery $(40 \%)$ and general function zones (sports, recreation, educational-experimental, servicing) that need to be planned in the area.

Sports fields. One of the earliest known schools with a separate gym building and sports ground [26] in the present Lithuania was the Queen Louise High School (archit. Luthje) built in 1891 in Klaipeda. Then the discipline of physical education was introduced in the schools of Prussia, to which Klaipeda belonged at that time.

The major breakthrough in the country's sport and physical education history occurred after regaining the statehood in 1918: the first public sports ground was constructed in 1922; in 1925 the schools' gymnastics contest was held in Kaunas [14]; in 1927, textbooks and tutorials on physical education in schools $[7,8]$ were first published; in 1929, the discipline of military training was introduced in the curriculum; in 1932, the Law on Physical Culture was adopted; in 1934, the first state Sports University was opened and one of the earliest methodical recommendations for the construction of sports fields was prepared [13]; 


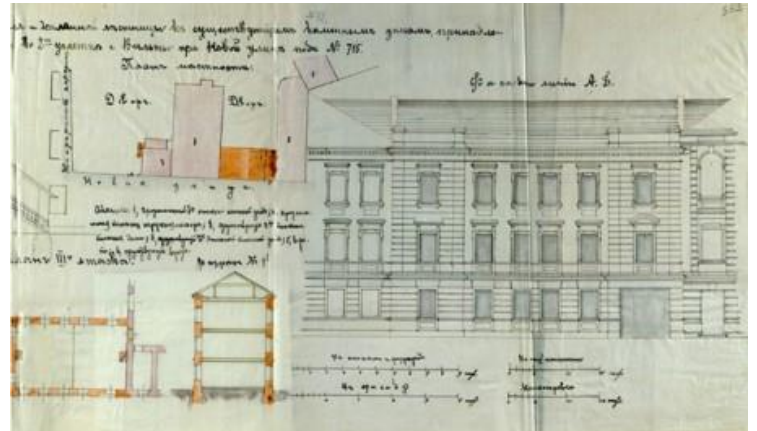

Fig. 1. Talmud-Tora Vocational School, Islandijos Str., Vilnius, 1890, 1899-1901, archit. Kiprijonas Maculevičius, Konstantin Korojedov. Source: LVIA_F.938.Ap.4.B.1977.

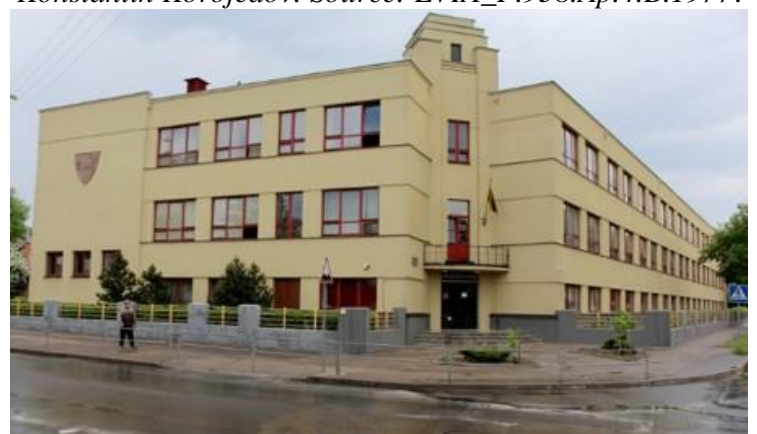

Fig. 2. Jonas Jablonskis Primary school for children of blue-collar workers, Aušros Str. 3, Kaunas, 1931, archit. Antanas Jokimas. Photo: L. Nekrošius, 2016.

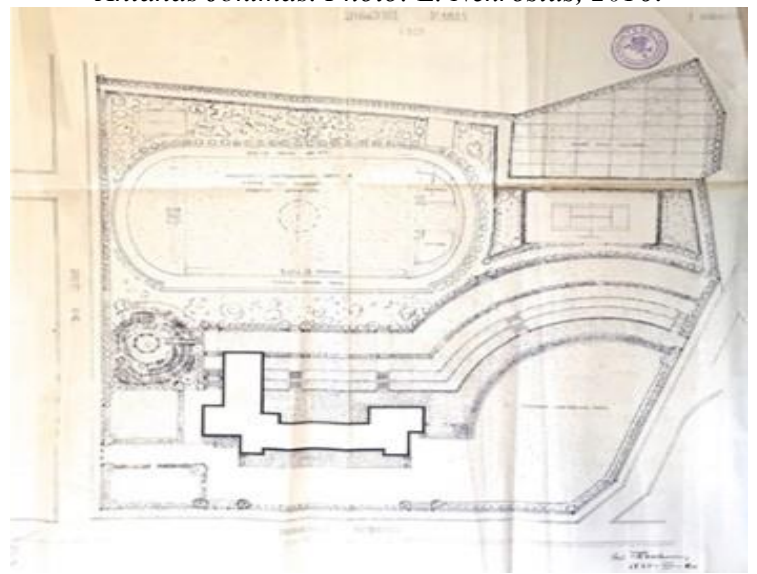

Fig. 3. High School in Kédainiai, 1935 (exploded in 1944), masterplan, archit. F. Bielinskis. Source: LCVA $16224525 l 8$.

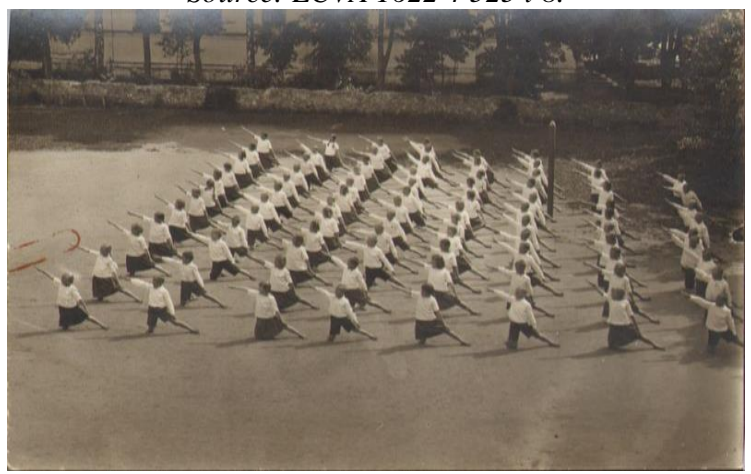

Fig. 4. Sport field of primary school No 1 in Užpaliai, Utena district, 1935

Source: (C) Lithuania's Education History Museum, photographer unknown.

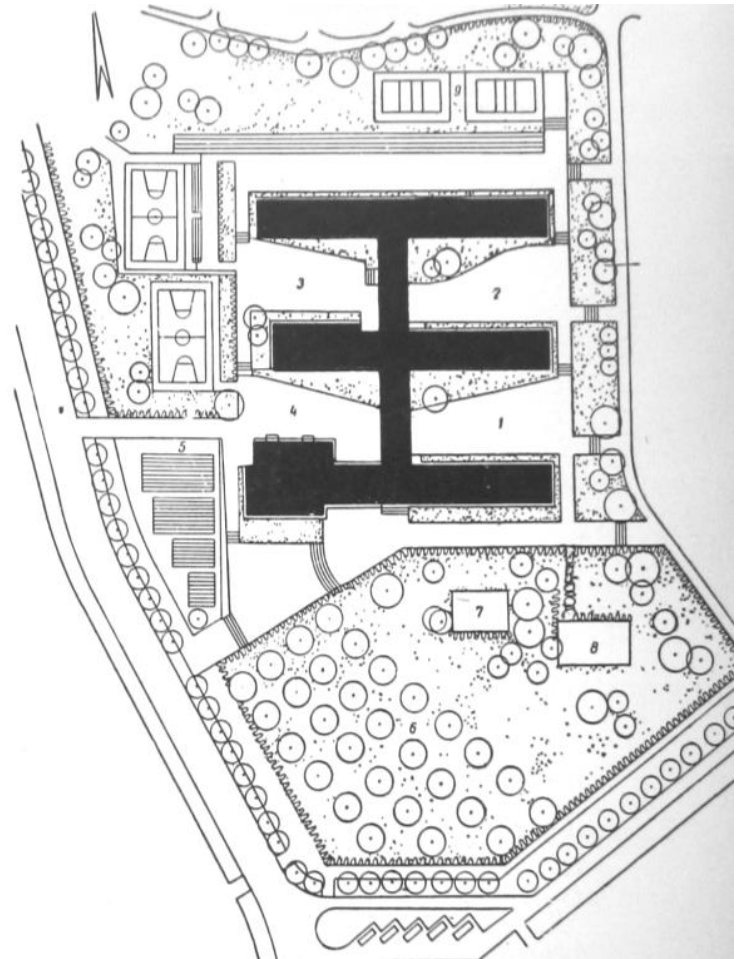

Fig. 5. Typical project of the secondary school for 964 pupils, 1962-63, master plan, archit. Leonas Mardosas.

Source: Sovietskaja architektura ezegodnik. Moskva, 1967, [2]

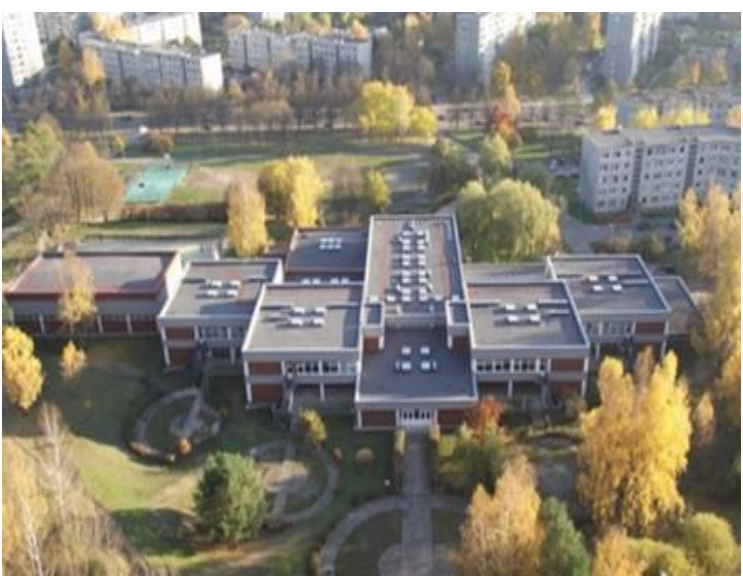

Fig. 6. Secondary school No 40 in Lazdynai, Erfurto Str. 23 , Vilnius, 1974, archit. Česlovas Mazūras. Photo: L. Nekrošius, 2011.

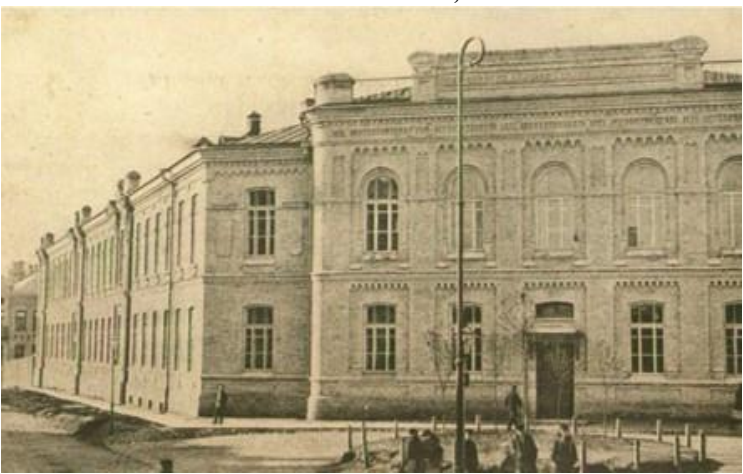

Fig. 7. Chemistry Technical School, Naugarduko gatve 24, Vilnius, 1901-1902, archit. Aleksandr Bykovsky, postcard. 


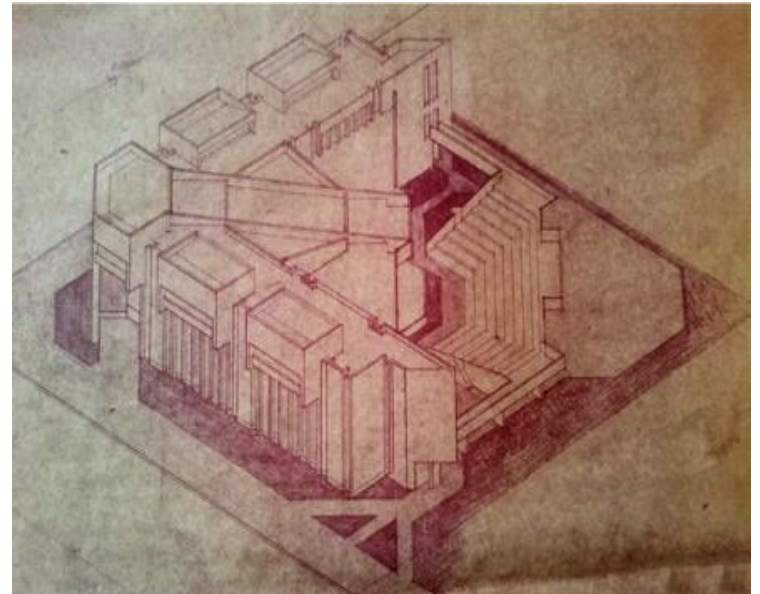

Fig. 8. Stasys Vainiūnas Art School

(unimplemented amphitheatre in the courtyard), Maironio St. 8, Palanga, 1981-1982, archit. Irena Likšiene. Source: I. Likšienè's personal archive.

in 1940, the PhD thesis on "The Role of Motion in the Educational Process" by Lithuanian scholar Jonas Laužikas was defended at Zurich University [4].

Sports halls and fields, in exceptional cases, even swimming pools [23] in the school projects of the 30's were already planned (Fig. 3). But some of these ideas were ahead of time, consequently were not realised or postponed. However, often schools provided for the possibility for physical activities (Fig. 4) much earlier than the political decisions were 1960 's and 70's, more than 70\% of the school area had to be allocated to sports. All schools had to contain the athletics, gymnastics, multifunctional (basketball, volleyball, pioneerball) playgrounds (Fig. 5). made [14]. In the 1950s, a few schools without the sports facilities were built, but situation was changing rapidly. According to the design standards of the In addition to this, larger schools were obligated to construct their football fields. The contemporary norms are not so strict. They refer that $35-40 \%$ of the plot area need to be designed for sports [17].

Establishment of the educational-experimental zone in the schoolyard is likely to be linked to the country's agricultural policy of the third decade. Then various initiatives were introduced aimed to teach the younger generation for advanced farming. One of the most prominent political projects of the time was establishment of the youth organization Young Farmers' Clubs in 1929 [20].

Vegetable, fruit, berry and flower gardens, seed-plot, plant breeding, zoology, meteorological observation zones, greenhouses, gazebo for open-air classes were precisely defined by the norms of the 1960's and 70's. These zones were designed, but the results of their implementation varied a lot.

The early schools' active recreation areas coincided with the sports grounds, passive - with the educationalexperimental zone. The obligation to form 3-4 separate active rest zones for different age groups and 1 for teenagers' calm rest were set up in the regulations of the1960's. In most cases, such zoning was formal and with some exceptions (Fig. 6) it is difficult to identify them in the courtyards of nowadays schools. Current legislation also provides for mandatory rest areas separate for primary and secondary school students.

Service zone is used for the maintenance transport, storage of waste and, back in the past, also for outdoor toilets. Beams for tethering horses of the first half of the $20 \mathrm{c}$. were changed into the small asphalted parking lots, mainly intended for catering areas. Improved cycling and pedestrian infrastructures of the school's surrounding neighbourhood today means not only the sustainable urban communication but is understood as the promotion of students' physical activity [15]. Customary for rural schools, bicycle racks started to be installed in urban schools at the end of the 20th century and slightly began to create a new typological element - covered bike parking - in the 21 st century.

Representation spaces usually coincide with other functional zones; however, we would like to draw attention to some aspects of such spaces.

According to the principle of homestead planning, a decorative flower garden was usually cultivated between the street and the building in rural schools. Urban school's gardening area traditionally was in the backyard. When at the beginning of 20th century, the main entrance was distracted from the street and small public space was formed in front of it, flower garden was moved from the backyard in here and changed its primary function from educational-experimental to representational (Fig. 7).

Official events (such as the beginning of the academic year), ceremonies (graduation) as well as community photo sessions often take place outside the building. Historical school located in the traditional city block usually uses its courtyard. Architects of the second half of the 20th century paid exclusive attention on the entrance space design. It became usual for schools in the free-plan neighbourhoods to have an exceptional entrance space working as a stage during events with a piazza in front, which can accommodate more people than the inside hall. However, there are some experimental solutions combining historical and modernist design approaches (Fig. 8).

\section{Community Needs in the Light of Building History, Education Theory and City Policy}

The demographic processes of the last decades and the country's economic opportunities have not stimulated the construction of new schools in Lithuania. Most of the schools used today were built in the 20th century. After the restoration of the Independence (1990), the national education system was reformed shifting from the unified secondary education to the three-part structure (primary, basic, 
gymnasium education). These changes substantially corrected the needs of school communities and the requirements of the education system for learning spaces. The educational legislation "encourages school communities to "invent" the school by developing its working patterns, environments and ways of education." [18].

Contemporary urban and architectural development is increasingly based on inhabitants' participation, but the communities still desperately need encouragement, support and know-how manuals from experts, including architects and landscape architects. Having identified the need for methodology, the researchers of the Faculty of Architecture, VGTU, have started experimental activities in order to form the theoretical model of the transformation of educational spaces.

A series of creative workshops have been set up to shape the guidelines for architects and school communities to focus on finding and implementing the common solutions.

Five workshops were organized on different aspects of transformation of educational environment. Three of them focused on schools of different levels and typologies (curators: Dolf Broekhuizen, Edita Riaubienè, Liutauras Nekrošius): "Contemporary Conception of Primary School" (2015), "The School Teenagers Want to Go" (2016), "Redesigning Technical Schools of Old Vilnius" (2017). These events were based on similar structure, stages and methodologies.

First of all, we appealed to architecture students' empathy for the topic and problem through the autoreflections (sensual reminiscences and experiences of their primary school; digging up teenagers' memories of their schooling; personal reflecting on the craft).

The second step was concerned with providing and collecting various kinds of information on the problem: bibliography, lectures on related topics, excursions to particular objects, meetings with members of school communities.

The third step was the articulation of the initial insights into the problem, and, finally, the last step the elaboration of the idea, the presentation of the solution.

The actual issues of primary school architecture were discussed at the workshop "Contemporary Conception of Primary School [24] (2015) considering the fact that physical environment has the greatest influence on an ever-evolving personality.

The area of the mass housing residential district Lazdynai in Vilnius (built in 1974, architects Vytautas Edmundas Čekanauskas, Vytautas Brèdikis) was chosen for the research aiming to analyse the transformation of its educational infrastructure and to discuss possible changes.

The additional argument to investigate the area of Lazdynai was the fact that this mass building structure is the only one recognised as modernist urban heritage in Lithuania. The preservation aspect here was a secondary one, but it allowed for a more comprehensive look at the values of the planned infrastructure and transformations determined by the changing needs of society.

The deeper analysis was performed focusing on five primary schools of the district. These objects are located in different architectural environments: a few are situated in the buildings of former kindergartens; others - in the structure of secondary school.

During the study visits to the objects, representatives of school communities presented in detail the school buildings, usage, processes and emerging needs in them, provided for the necessary materials, but their participation in the creative process has been little and episodic.

The workshop participants contextualised the selected information by asking three questions. What concepts and recommendations does the modern educational theory provide? What does the municipality, as the establisher of the school, anticipate? What does the school community expect, what dreams and ambitions do they have? Having assessed all this, they made architectural suggestions on how the space could be changed.

Empirical studies, conversations with schoolchildren highlighted the school outdoors as extinct from the memory of people, and hardly used today. Referring to safety at school, children are rarely allowed to enter the schoolyard; the outdoor space is used for education only when the internal temperature in the classes reaches unbearable level.

The physical condition of sports grounds often does not encourage their intensive use. However, there are a few surprising and encouraging examples. Some schools located in dense urban environment have minimal outdoor spaces, but they use it intensively and in different ways.

Such insights led the participants of the workshop to focus on rethinking of school landscapes and their integration in educational process. Each particular school situation is unique and therefore the scenarios for conversion and use of their outdoor spaces for teaching and learning purposes can vary widely. The workshop participants identified a few solutions oriented towards integrating the outdoor spaces adjacent to classrooms into the educational process. Following the logic of Herman Hertzberger [11], it was suggested to provide an additional transit space to the classroom - an outdoor patio or loggia tailored for education. Assuming that unexpected spaces can attract and motivate the learners, stimulate their cognitive abilities, it was proposed to use the existing roofs for recreation and education and restore the disappeared connections between inner and outer spaces (Fig. 9). 
It has been observed that the successful combination of school priorities can stimulate operational programs that improve the use of outdoor area. The primary school "Svaja" is overcrowded, so its outdoor territory is intensively used for games and recreation. The school is proud of its theatre club, so it has been suggested to install an amphitheatre, that can be used for occasional events, for children's games and communication, also to strengthen the school identity (Fig. 10).

The participants of the workshop clearly understood the challenges faced by a primary school situated in a large secondary school building. They perceived the extraordinary need for a green, safe, pleasant and interesting outdoor environment for the young pupils and imagined it like "Oasis" in a large unstructured school ground. It was suggested therefore to construct a wooden terrace close to the classes, articulated with flower beds and other plants. The semi-open school yard could provide for different functional zones that meet different moods, experiences and needs: grass and other greenery - to be in nature and with nature; amphitheatre - to be above, to feel visible; equipped playground - to enjoy physical activity, movement and being with others; multifunctional area - to be free to choose the way of being there (Fig. 11).

The other group of students suggested to arrange the outdoor area by providing the most suitable place for each purpose, interest or activity.
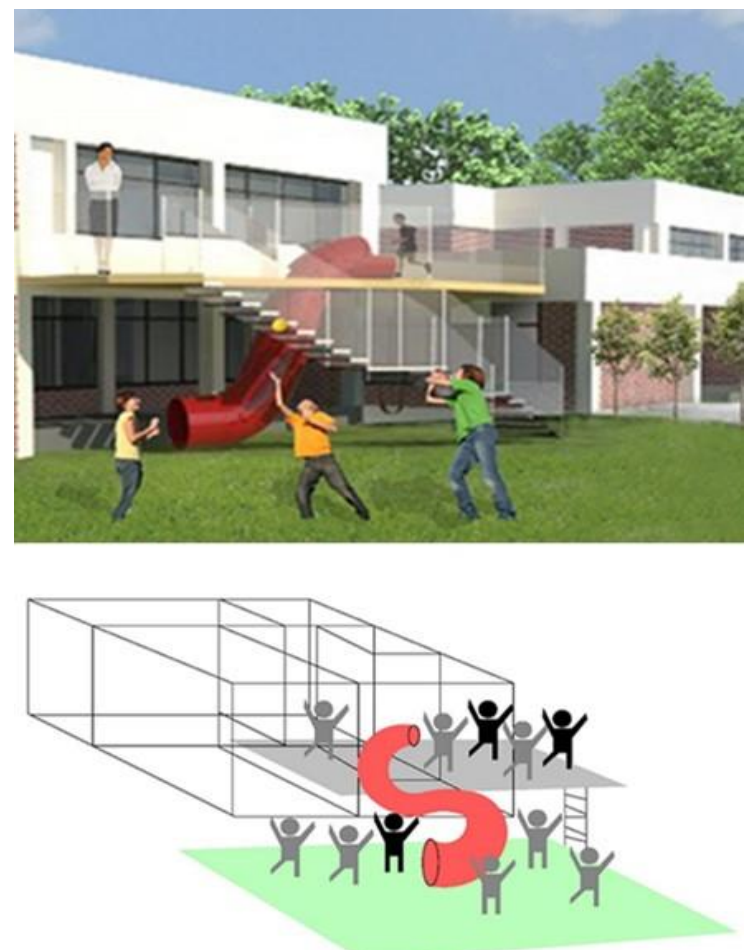

Fig. 9. The restoration of disappeared connections between inner and outer spaces, "Chaos in the box"

Created by K. Galvydytè, I. Kundreckas, 2015

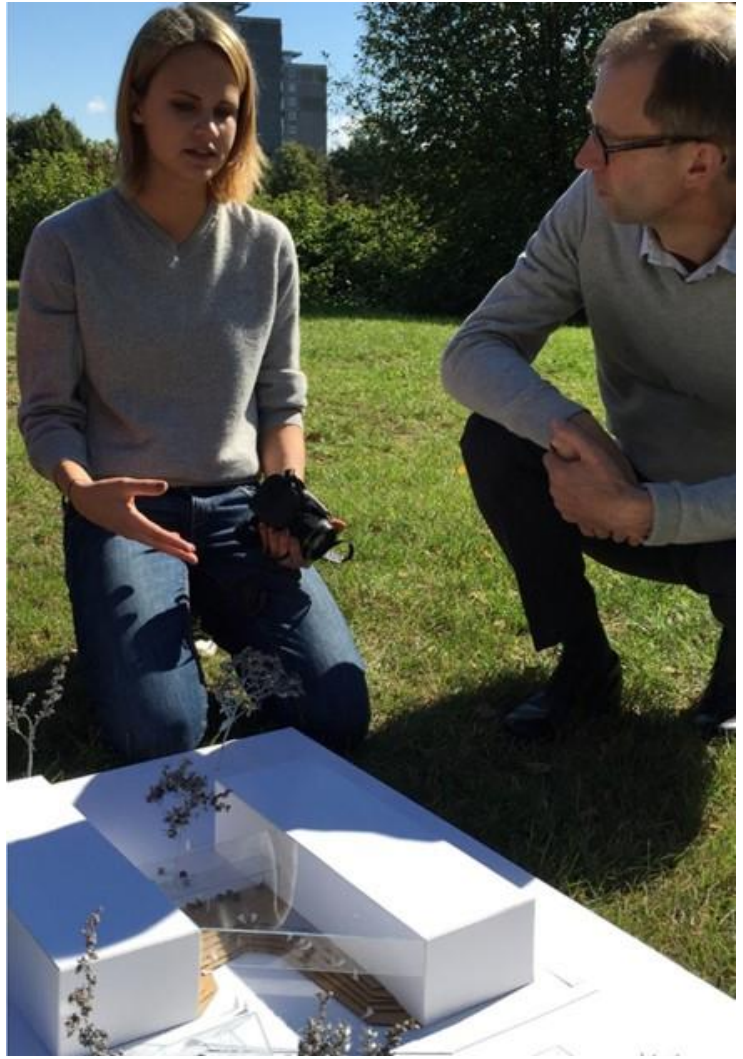

Fig. 10. Curator D. Broekhuizen consult student near the model of the primary school "Svaja"

A. Šlepikaitè, V. Mankevičiùtè, 2015.

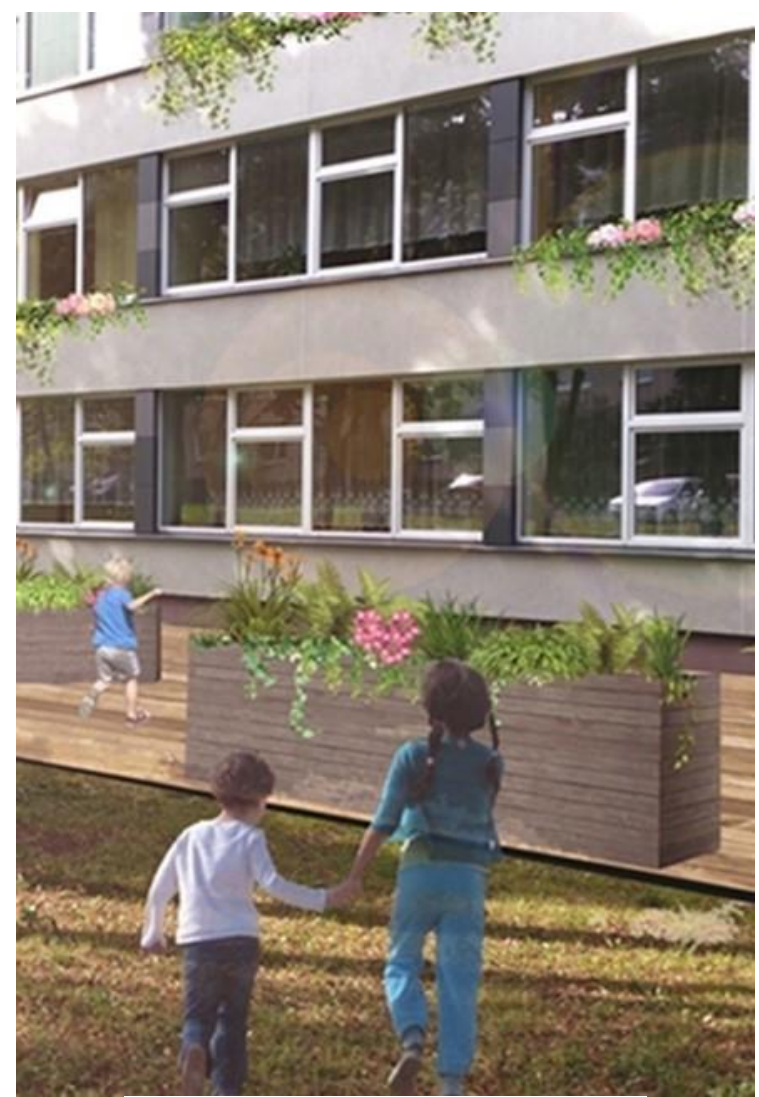

Fig. 11. "Oasis", Lazdynu secondary school.

Created by J. Jaruševičiùtè, G. Ribikauskaitè, K. Burbaitè, 2015. 

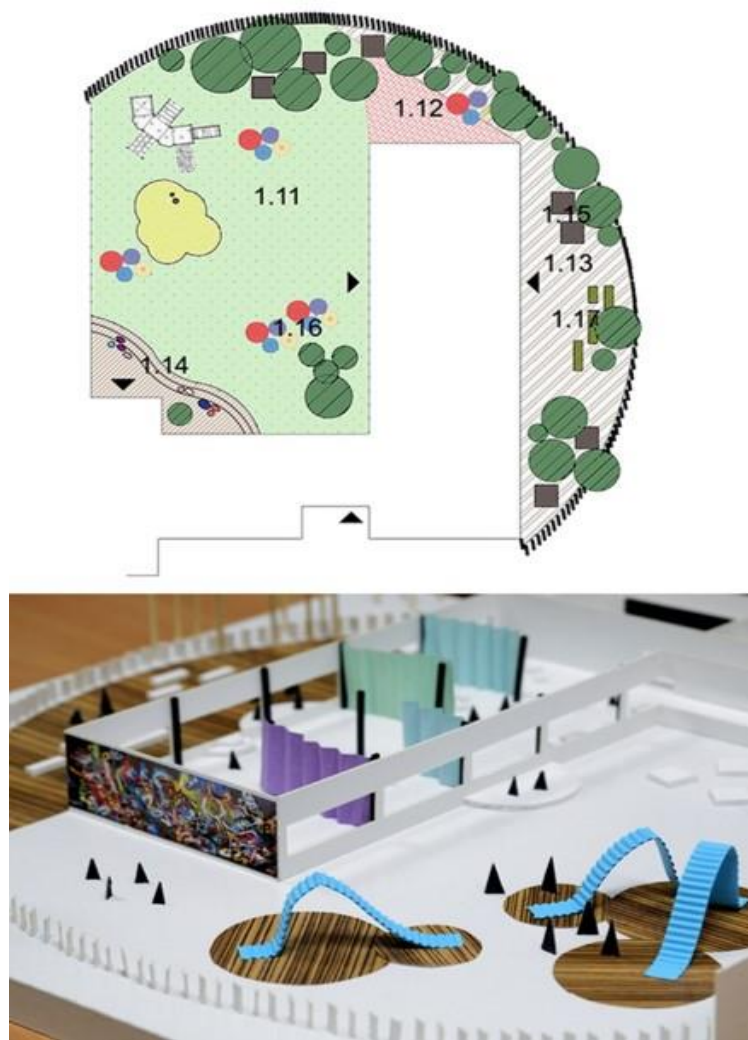

Fig. 12. "The Open up", Sausio 13-osios school, S. Subačiūte, A. Janulaitis, 2015. 1.11 playground, 1.12 art playground, 1.13 science playground, 1.14 amphitheatre,

1.15 pavilions and pergolas, 1.16 outdoor furniture, 1.17 vegetable beds.

The school territory was understood as universe, still unfamiliar and frightening to a child. The arrangement of the outdoor area for the primary school pupils was suggested as detached by natural and architectural elements in order to define clearly the boundaries of the safe children's world. The complexity of this "world" was expressed by various places, spaces and functions: playground, art ground, science ground, amphitheatre, pavilions and pergolas, outdoor furniture, vegetable beds, etc. (Fig. 12).

The results of architectural workshops that analysed primary education environment confirmed the hypothesis that the universal solutions fit for everyone are not suitable for the individual-oriented modern education. The proposals for the transformation of school outer space allowed to see some guidelines for change but denied the possibility of a unified solution. The uniqueness of each situation is determined by the identity of each school and its community. This insight strongly indicates the importance of school community in the process of design and re-creation of educational environment. Along with the research on educational architecture, the direction of the design-build studio approach [25] was started and the first project implemented in the courtyard of VGTU Architectural faculty [21]. The gained experience of design and implementation [16] was applied in the workshop at the catholic high school in Lazdynai in 2016.

\section{School Ground as a Collectively Developed Play-scape}

The paper is focused on the participatory design cases developed in cooperation with schools mainly located in the post-socialist residential district Lazdynai in Vilnius, which is an example displaying the current considerations on adaptation of the modernist architectural legacy to nowadays and future society's needs.

Lazdynai is the first district in Vilnius, where the concept of rayon or "sleeping" district was implemented at an almost complete scope. In 1974 the design team of Lazdynai was awarded the highest state prize of the time - the Lenin's Prize. Thus later on the district was promoted as an etalon of soviet urban design, but today its mono functionality and structural rigidity towards the change is one of the main issues in terms of buildings and urban public spaces. Although the inhabitants of Lazdynai themselves attempted to transform the semi-public spaces on their own initiative trying to personalize and fragment them or adapt to informal functions, but these initiatives did not reach the main public spaces of the district due to financing issues and, most importantly, the lack of visions and impulses from the community itself.

As soon as the trends of participatory processes reached Lithuania in 2010, the idea that the community itself with support of experts should engage in, initiate and maintain the transformation of its environment and the specifics of Lazdynai district led to a noticeable concentration of activist projects carried out by NGOs and academic institutions aiming to activate rethinking of alternative programs of the public space together with the community. In this context architects also took a chance not only at testing the participatory design in theory, but also putting it into professional practice. Full community's involvement in the participatory design led by architects as the mediators; understanding the urban space from the perspective of its users before making any changes; exercising the imagination as the catalyst of rethinking and rediscovering the everyday urban spaces were the key goals of an international summer school "Play East!" (2016) in Lazdynai.

The summer school was organized by the Faculty of Architecture VGTU and curators Barbara Pampe and Vittoria Capresi (baladilab, Germany), who had contributed the methods and expertise in improving the courtyards of schools and transforming them into playing landscape (playscape) through "LearningMove-Play-Ground" summer schools series in Germany and Egypt. The summer school was hosted by the Blessed Teofilius Matulionis High School 
(former Vilnius Versme High School) itself matching the philosophy of the school: education in this school is based on the tradition of St. Marie-Eugénie, according to which the quality education should be based on responsibility and social action, challenges and current issues, community feeling and cooperation.

The school's aspirations to encourage children spending more time outdoors and the need of proper infrastructure for outdoor education necessitated the changes of the school ground. The user's involvement with the school grounds is a tangible expression of the school's philosophy and educational practice - the philosophy and practice create the landscape [2]. Following this idea, the school's community and architects' team strived to create a multifunctional landscape representing the philosophy of the school. Landscape as functional sculpture; as a set of game elements; as learning space; as inspiring amorphous shape in a monotonous setting of mass-housing meets the expectations of the school community members in anticipation that diversity would have a lasting supportive effect on children's activity outdoors [3]. Understanding before making changes. The curators of the summer school "Play East!" adapted the methods of the participatory design, which covered several stages: input phase; workshop with children and teachers; design phase;

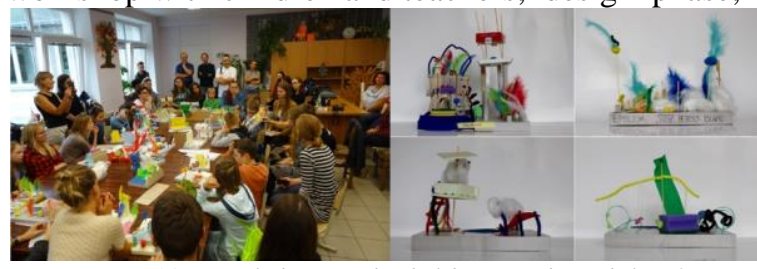

Fig. 13. Workshop with children and models of Atmospheres.Source: "Play East!” team, 2016.

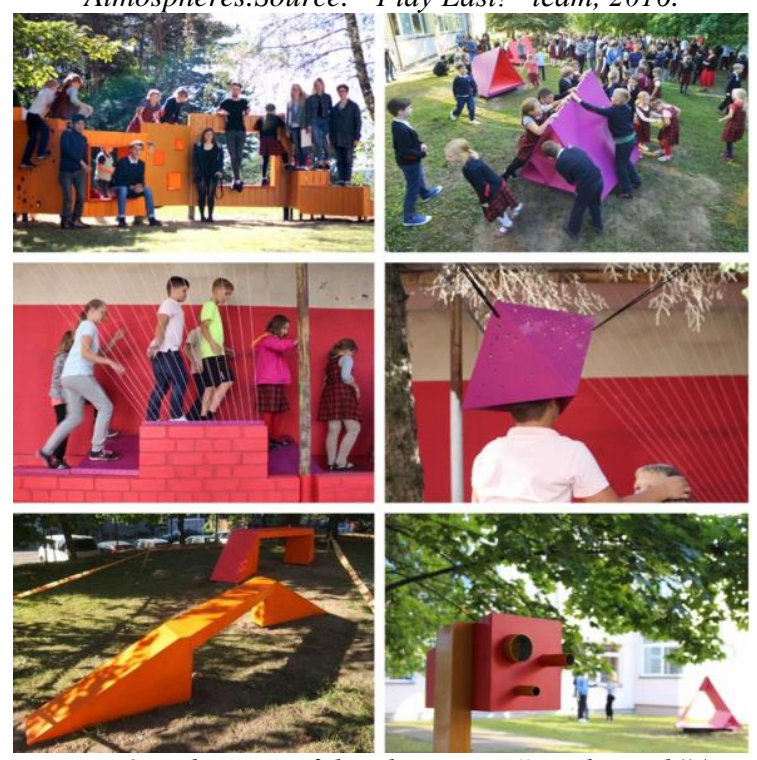

Fig. 14. Elements of the playscape: "Brick-Work"( transferring the atmosphere of Obstacles), "Wall" (Observing and Safety), "Tents" (Perpetual Movement), "Hidden Elements"

(Changing Perspective) Source: "Play East!" team, 2016. implementation phase; inauguration. During the workshop the needs of the school were explored from the perspective of teachers as experts, who know their students and spaces of the school the best, are aware of the educational process and its improvement.

Understanding the present condition and expectations from the perspective of school community is one of the essential aspects of the participatory process. "Like the caution to understand before interpreting the social world of school grounds, many commentators strongly urge thorough understanding before adjusting it to make changes on the school grounds" [6]. Exploration of the school together with its community may reveal the hidden potential and identity of the school, therefore the context-aware transformations rather than predesigned solutions are more appropriate and match the identity of the school's community.

Imagination exercises. The workshop with children aimed at shifting away from the everyday processes and spaces of the school, therefore the exploration of the desirable atmospheres was chosen as participatory design tactics, helping to escape the ready-made images of the school ground and allowing some space for uncertainties and contingencies in design. Communication through atmospheres, in the forms of models, installations, drawings, collages and storytelling avoids the fixed code needs and ideas that are often difficult to communicate or implement [22]. On the other hand, the abstract thesaurus of the atmosphere, and the unleashed imagination trigger the unexpected forms and functions of the space. The Atmospheres workshop in Lazdynai was focused on revealing the mood and scenario of The Dream Day. Assisted by the architecture students, children visualised their own dream days through the models and storytelling (Fig. 13) thus uncovering the wide range of auras and activities of their leisure.

Architect as mediator. The design phase set the architecture students to extract the main keywords of children dreams (e.g. safety, observation, perpetual movement, changing perspective, obstacles) and transfer them into the design of the playing landscape, which in the end resulted as five landscape elements integrated into the school ground - Wall, Brick-Work, Balancing Track, Hidden Elements and Tents. The design and building phases introduced the architecture students as the future professionals to the currently changing role of the architect as they were prompted to act rather as creative links or moderators between the architecture and its users, taking the responsibility to perceive, synthesize and transfer the expectations and needs of the community into architectural form; furthermore, the students worked in groups and collectively elaborated the elements of the landscape, that resulted in the absence of the authorship and put all the persons involved on the same level of co-creatorship. On the other hand, involvement into 
the full scope of school ground transformations was crucial experience for the school's community too, as they went through all the design-build stages rethinking the school, imagining, discussing the project, finding the sponsors, building the landscape elements themselves. Therefore, the architects had to design the simple, low-cost playscape feasible to efforts of the community itself and the sponsors involved (Fig. 14), and showcase this pilot project hoping to inspire other communities to act "horizontally" and in anticipation that residents especially children and students as the upcoming future society - will become the creative partners and co-creators of the urban spaces.

\section{Conclusions}

The strict functional zoning of school territories built in the 1930's-1980's has lost its relevance today due to the changed mode of use. There is a need to optimize the use of these spaces by adapting them to several functions, seeking polyfunctionality. This is a particularly welcome trend, when schools are located on smaller parcels.

The analysis of development of school grounds has discovered that a school territory in various periods was used for physical activities and training. Other functions emerged as complementary and diversifying.

The historic research and results of the workshops have shown that importance, scope and spatial positions of functions of school grounds have been changing; the recreation and representation [functions] are close related and using the same area, the representation and experimental learning (gardening) have been matched; physical training and sports function can be transferred into relaxation. These exchanges and mergers indicate that school grounds respond to the changing needs.

The research has highlighted that various functions of the school outdoor territories have been planned, have not been implemented or become viable. Contemporary education theory advocates outdoor learning, learning in unexpected spaces as a tool for better knowledge absorption. Therefore, the restoration of the disappeared and development of new connections between the outer and inner recreational spaces is a priority.

Representative greenery lost its primary educational function, but it has a potential to be a tool not only for basics of biology, but also plant design and landscape architecture studies.

The occurrence of bicycle parkings in school yards, re-establishment of links between schools and adjacent parks should be understood as a part of policy for sustainable mobility and healthy environment.

Construction of open and covered outdoor amphitheaters in the yard can lead to wider engagement of schools as well neighborhood communities into school life.

Participatory design-build studio is one of the methods to achieve the up-to-date learning environment that is collectively developed by the students and schools' communities. The case of Blessed Teofilius Matulionis High School designbuild has revealed three main aspects: (1) collectively developed playing landscape as functional sculpture; as a set of game elements; as learning space; as inspiring amorphous shape in a monotonous setting of mass-housing meets the diverse expectations of the school community, thus the diversity of landscape has a lasting supportive effect on children's activity outdoors. (2) Understanding of spaces and processes of school together with its community reveal the hidden potential and identity of the school, therefore the context-aware transformations rather than predesigned solutions are more acceptable to the community. (3) Community's participation at all stages of the design-build process preconditions the permanent maintenance and further development of school grounds by the community itself.

\section{References}

1. Abbott, J. Sharing the City. Community Participation in Urban Management. London: Routledge, 1996. 256 p.

2. Adams, E., Learning through Landscapes: A Report on the Use, Design, Management and Development of School Grounds. Winchester: Learning through Landscapes, 1990. 282 p.

3. Brink, L. A., Nigg, C. R., Lampe, S. M. R. et al. Influence of Schoolyard Renovations on Children's Physical Activity: The Learning Landscapes Program. American Journal of Pulbic Health, 2010, Vol. 100(9), p. 1672-1678.

4. Bukauskienė, T. Lietuvos mokyklai 600 metu (600 years of Lithuania's School). Vilnius: Viliaus Užtupo leidykla, 1997, 64.

5. Burke, C., Grosvenor, I. The School I'd Like: Revisited. London, New York: Routledge, 2015. 39 p.

6. Casey, T. School Grounds Literature Review, 2003. [Available at:] http://www.playscotland.org/wpcontent/uploads/assets/Documents/SSGSLiteratureReview.pdf

7. Dineika, K. Sportas mokykloje. Laun-tenisas (Sport at School. Tenis). Kaunas: Varpas, 1929. 40 p.

8. Dineikienè, P., Dineika, K. Fiziško lavinimo vadovèlis pradžios mokyklai (Physical Education Tutorial for Primary school). Kaunas: Vilniaus spaustuvè, 1927. 156 p.

9. Fung, A. Empowered Participation. Reinventing Urban Democracy. New Jersey: Princeton University Press, 2004. $336 \mathrm{p}$. 
10. Hercoga, L., Ziemel̦niece, A. The Contextual Search in the Landscape Space of the School and Manor Building. Scientific Journal of Latvia University of Agriculture Landscape Architecture and Art, 2018, Vol. 11(11), p. $62-68$.

11. Hertzberger, H. The schools of Herman Hertzberger. Rotterdam: 010 Publishers, 2009. 176 p.

12. Hicker, S., Mohan, G. Participation: From Tyranny to Transformation? Exploring new approaches to participation in development. London: Zen Books, 2004. 293 p.

13. Jankevičiūtė, G. Playing to Win: Sports Architecture. In: Architecture of Optimism. Vilnius: Lapas, 2018, p. $216-227$.

14. Jaruševičius, V., Selliené, A., Laučienè, S. Kauno "Saulès” gimnazija („Saulès“ High School in Kaunas). Kaunas: [Taurapolis], 2013, p. 43-45.

15. Jones, N., R., Jones A., Sluijs, E., MF, van. School Environments and Physical Activity: The development and testing of an audit tool. Health \& Place, 2010, Vol. 16(5), p. 776-783.

16. Kraus, C. Designbuild Education. New York: Routledge, 2017. 240 p.

17. Bendrojo lavinimo mokyklos higienos normos ir taisykles (Secondary School Hygiene Norms and Regulations), Lietuvos Respublikos sveikatos apsaugos ministerij, Lietuvos higienos norma HN 21:1998. Official Gazette, 1998, No. 112, December 12, p. 3117.

18. Geros mokyklos koncepcija (Concept of Good School). Lietuvos Respublikos švietimo ir mokslo ministerija, Icsakymas dèl geros mokyklos koncepcijos patvirtinimo (The Order by the Minister of Education and Science of the Republic of Lithuania), No. V-1308; Vilnius, 21.12.2015.

19. Lukšionytè-Tolvaišienė, N. Istorizmas ir modernas Vilniaus architektūroje (Historic Revival and Modern Architecture in Vilnius). Vilnius: VDA, 2000, p. 46-49.

20. Mačiulis, D. Tautine mokykla: žvilgsnis $\dot{y}$ tautininku švietimo politikq (National School: a Look at the Policy of Nationalist Education). Vilnius: Istorijos institutas, 2017. 150 p.

21. Navickienè, E., VGTU Architektūros fakulteto kieme - miško namelis (Cabin in the Courtyard of the Architecture Faculty). Statyba ir Architektūra, 27.09.2015 [online 30.07.2018] https://sa.lt/en/architekturos-fakulteto-kieme-miskonamelis/

22. Learn-Move-Play-Ground, Pampe B., Capresi, V. (eds.). Berlin: Jovis, 2013. 143 p.

23. Petrulis, V. Educational Architecture and the Modernisation of Society. In: Architecture of Optimism. Vilnius: Lapas: 2018, 178-191.

24. Riaubienė, E., Broekhuizen, D., VGTU. Sovietmetị menantys mokyklų pastatai: ar čia gali vystytis kūrybingos asmenybės? (Soviet-era School Buildings: Can Creative Personalities Grow up There?). Centras [online 30.07.2018.] http://www.interjeras.lt/naujiena/Sovietmeti_menantys_mokyklu_pastatai

25. Stonorov, T. The Design-build Studio: Crafting Meaningful Work in Architecture Education. New York: Routledge, 2018, 269.

26. Tatoris, J. Senoji Klaipèda. Urbanistinè raida ir architektūra iki 1939 metu (Old Klaipeda. Urban Development and Architecture before 1939). Vilnius: MEL, 1994. 209 p.

27. Государственный комитет по делам строительства СССР. Cтроительные нормы и правила. Общеобразовательные школь и иколь-интернаты. Нормы проектирования СНиП П-Л.4-62. (Building Regulations. Secondary Schools and Boarding Schools. Design Standards) Москва: Издательство литературы по строительству, 1964. 34 p.

28. Государственный комитет по делам строительства СССР. Строительные нормы и правила. Нормы проектирования Общеобразовательные школы и школь-интернаты СНиП II-65-73 (Building Regulations. Secondary Schools and Boarding Schools. Design Standards). Москва: Стройиздат, 1974. 36 p.

\section{INFORMATION ABOUT THE AUTHORS:}

Liutauras Nekrošius - Architect, Doctor of Humanities (Architecture, VGTU, 2009), Associate Professor at the Faculty of Architecture, VGTU. The current research fields: history and heritage protection of modern architecture, educational architecture. E-mail: Liutauras.Nekrosius@vgtu.lt

Edita Riaubienè - Architect, Doctor of Humanities (Architecture, VGTU, 2003), Associate Professor at the Faculty of Architecture, VGTU. The current research fields: architectural theory, architectural heritage. E-mail: Edita.Riaubiene@vgtu.lt

Indrė Ruseckaitė - Architect, Doctor of Humanities (Architecture, VGTU, 2013), Associate Professor at the Faculty of Architecture, VGTU. The current research fields: history and heritage protection of modernist architecture, participatory design. E-mail: Indre.Ruseckaite@vgtu.lt

Kopsavilkums. Rakstā izklāstīta skolu pagalmu izglītojošā nozīme un pierādīts apgalvojums, ka šīs teritorijas ir izmantojamas, lai izglītotu jaunās paaudzes, veicinot sadarbību apkārtējās vides veidošanā. Lietuvas skolu arhitektūras izpēte pēdējā desmitgadē liecina par skolu pagalmu izmantošanu, kas varētu tikt raksturota kā "Aizmirstā Telpa". Izglītojošais personāls pievērš īpašu uzmanību mijiedarbībai starp mācīšanos un spēlēšanos. Urbānā dārzkopība, vides novērošana, īpaši veidotas studijas ir kḷuvušas par neatṇemamu dalı no sekundārās un pat primārās izglītības sistēmas. Šāda veida izglītojošām aktivitātēm ir nepieciešama atbilstoša vide. Lielākā daḷa skolu Lietuvā ir būvētas starpkaru un padomju periodos un ne vienmēr tās spēj apmierināt mūsdienu izglìtības vides prasības. Arhitekti, ainavu arhitekti un pilsētplānotāji, saistībā ar izglītỉbai piemērotas vides projektēšanu, raugās uz sadarbību ar sabiedrību kā šķērsli vai formālu nepieciešamību. Kopš 2014 gada VGTU Arhitektūras fakultāte ir uzsākusi darbību kā katalizators, veicinot diskusijas un alternatīvus redzējumus, saistībā ar skolu telpu pārmain̄ām. 